\title{
EFFECT OF MODERATE STATIC MAGNETIC FIELD ON HUMAN BONE MARROW MESENCHYMAL STEM CELLS: A PRELIMINARY STUDY FOR REGENERATIVE MEDICINE
}

\author{
Kaya MOLO, Emel ORDU* \\ Department of Molecular Biology and Genetics, Faculty of Arts and Science, Yıldı Technical University, İstanbul, \\ TURKEY
}

Cite this article as:

Molo K. \& Ordu E. 2021. Effect of Moderate Static Magnetic Field on Human Bone Marrow Mesenchymal Stem Cells: a Preliminary Study for Regenerative Medicine. Trakya Univ J Nat Sci, 22(1): 35-42, DOI: 10.23902/trkjnat.806802

Received: 07 October 2020, Accepted: 21 January 2021, Online First: 17 February 2021, Published: 15 April 2021

Edited by:

Reşat Ünal

*Corresponding Author:

Emel Ordu

bemel@yildiz.edu.tr

ORCID iDs of the authors:

K.M. orcid.org/0000-0001-6168-2058

E.O. orcid.org/0000-0003-3060-2806

Key words:

Bone marrow mesenchymal stem/stromal cells,

Static magnetic field,

Osteogenesis

\begin{abstract}
Static Magnetic Field (SMF) is one of the biophysiological stimulants which modulates physiological processes in different cell lines. Mesenchymal stem cells (MSCs) are important biological tools for regenerative medicine. Although it is known that SMFs cause a change in cellular membrane polarization, oxidative product concentrations, gene expression patterns and cell propagation rates, depending on exposure time and intensity, their effects on MSCs have not been properly explained yet. In this study, MSCs derived from human bone marrow were treated with moderate $328 \mathrm{mT}$ SMF by using cylindric Neodymium Iron Boron $\left(\mathrm{Nd}_{2} \mathrm{Fe}_{14} \mathrm{~B}\right)$ magnets to investigate its influence on orientation, proliferation rates and morphologies. Results showed that the treated cells gained more homogenous orientation than the non-treated cells, however SMF influence did not significantly change proliferation rates.

The cells were grown under both chemically osteogenic induction and SMF to observe the osteogenic differentiation and biomineralization. Alkaline phosphatase (ALP) activity decreased significantly in the cells treated with SMF compared to the control groups. Alizarin Red S staining showed that mineralization also decreased in the cells. The results showed that an easily produced moderate SMF can be a useful physical stimulant to control the fate of MSC both in vitro and in vivo.
\end{abstract}

Özet: Statik Manyetik Alan (SMA), farklı hücre hatlarında fizyolojik süreçleri düzenleyen biyofizyolojik uyarıcılardan biridir. Mezenkimal kök hücreler (MKH'ler) rejeneratif tıp için önemli biyolojik araçlardır. SMA'ların yoğunluğuna ve süresine göre hücre membran polarizasyonunu, oksidatif ürün konsantrasyonlarını, gen ekspresyon modellerini ve hücre çoğalma oranlarını değiştirdiği bilinmesine rağmen, MKH'ler üzerindeki SMA etkileri henüz tam olarak açıklanmamıștır. Bu çalışmada, insan kemik iliği kaynaklı MKH'ler, silindirik Neodimyum Demir Bor $\left(\mathrm{Nd}_{2} \mathrm{Fe}_{14} \mathrm{~B}\right)$ miknatıslar kullanılarak orta derecede $328 \mathrm{mT}$ SMA etkisinde bırakıldı ve hücrelerin oryantasyonu, çoğalma oranı ve osteojenik farklılaşma potansiyelleri incelendi. Sonuçlar, tedavi edilen hücrelerin, tedavi edilmeyen hücrelerden daha homojen bir yönelim kazandığını, ancak SMF etkisinin çoğalma oranlarını önemli ölçüde değiştirmediğini gösterdi.

MKH'ler, osteojenik farklılaşmayı ve biyomineralizasyonu gözlemlemek için hem kimyasal olarak osteojenik indüksiyon hem de SMA altında büyütüldügünde, Alkalin Fosfataz (ALP) aktivitesi kontrol gruplarına kıyasla önemli ölçüde azaldı. Alizarin Red S boyaması, uyarılan hücrelerde mineralleşmenin de azaldığını gösterdi. Sunulan sonuçlar, kolayca üretilen orta düzeyde bir SMA'nın in vitro veya in vivo olarak MKH kaderini kontrol etmek için yararlı bir fiziksel uyarıcı olabileceğinin altını çizmektedir.

\section{Introduction}

In medicine, morphological and functional repair techniques, as well as regeneration of damaged or aged cells, tissues, or organs, are rapidly growing. These approaches need available cell sources that provide appropriate new tissue components or paracrine effects. Due to this reason, stem cells have been gaining much attention for the last three decades (Rajabzadeh et al. 2019, Suman et al. 2019). 
Stem cells are commonly characterized by their unspecialized nature and their high ability for selfrenewal and differentiation into functional cell types of the organism. After the embryonic development stage, multipotent stem cells reside in numerous tissues of the body. Tissues conserve their continuity and regulate their micro-environment by the functions of these stem cells (Rajabzadeh et al. 2019, Suman et al. 2019).

A new type of multipotent stem cells derived from bone marrow was discovered by the pioneering studies of Friedenstein et al. in the 1960s. These cells adhere to plastic surfaces and have a fibroblastic appearance. Although Friedenstein called them osteoprogenitors, subsequent studies showed that they can differentiate into osteoblasts, chondrocytes and adipocytes, and regulate the hematopoietic microenvironment in the bone marrow. This special stem cell type is currently known as mesenchymal stem/stromal cells (MSCs) (Keating 2017, Trohatou \& Roubelakis 2017).

Although MSCs were first isolated from bone marrow, they can also be isolated by less invasive techniques from adipose tissue, placenta, Wharton jelly, umbilical cord blood, and amniotic fluid. In addition to their high selfrenewal and differentiation potential in vitro and in vivo, they have paracrine effects that promote immunomodulation in addition to anti-apoptotic and antioxidative effects (Brown et al. 2019). These properties of MSCs make them a good tool for regenerative medicine.

During embryonic development and through the entire life of an organism, cells are constantly exposed to a variety of mechanical stimulations, e.g., muscle force, gravity, blood flow and other physical forces or processes. The interactions between cells and mechanical or physical factors are critical to the health and function of various tissues and organs of the body and are believed that they have important roles in diseases, e.g., atherosclerosis, osteoarthritis and osteoporosis (Guilak et al. 2009).

A static magnetic field (SMF) is described as a constant, non-changing vector field of an electrical current or a permanent magnet. The SMF is also a force that interacts with biological systems (Lohmann \& Lohmann 2019). Magnetic Resonance Imagining (MRI) presents one of the interaction examples between SMF and tissues, cells or biomolecules (Marycz et al. 2018). Magnetism and its effects on healing also have a place in both traditional and modern medicine (Markov 2007, 2015).

We aimed to seek interaction between bone marrowderived mesenchymal stem/stromal cells (BM-MSC) and moderate SMF in this preliminary study.

\section{Materials and Methods}

Bone Marrow Mesenchymal Stem/Stromal Cells Cell Culture

Cryopreserved human BM-MSCs were purchased from Stem Cell and Gene Therapy Research and
Application Center, Kocaeli University-Turkey. NutriStem Cell XF Basal Medium (Cat.\# 05-200-1A, Biological Industries-USA) supplemented with NutriStem XF Supplement XF (Cat.\# 05-201-1U, Biological Industries-USA) for BM-MSC propagation or Stempro Basal Medium (Cat.\# A10069-01, Thermo Fisher-USA) supplemented with Stempro Osteogenesis Supplement (Cat.\#A10066-01, Thermo Fisher-USA) for osteogenesis induction of BM-MSCs were used in cell cultures. The cells were incubated at $37{ }^{\circ} \mathrm{C}$ with $5 \% \mathrm{CO}_{2}$ and $100 \%$ humidity (Biosan ES20 incubator-Latvia) in all experiments.

Static Magnetic Field Source and Magnetic Flux $\underline{\operatorname{Density}(B)}$

Two cylindrical Neodymium-Iron-Boron $\left(\mathrm{Nd}_{2} \mathrm{Fe}_{14} \mathrm{~B}\right)$ magnets with $22 \mathrm{~mm}$ diameters (Mıknatıs Teknik-Turkey) were used as SMF sources. The magnets were on top of each other underneath the 12-well plate (TPP-USA) (Figs $1 \mathrm{a}, \mathrm{b})$. Each of the magnets has enough surface area to cover one of the assay wells of 12 -well plate (Fig. 1c). The diameter of each well in the 12-well plate was $21 \mathrm{~mm}$. The magnetic field flux density or magnetic induction (B) produced by two magnets on top of each other was measured as $328 \mathrm{mT}$ by AC/DC Magnetic Meter PCEMFM 3000. B is the number of lines of force passing through a unit area of material (Stefanita CG 2012; Wills $\&$ Finch 2015). All control groups were grown in Earth's magnetic field.
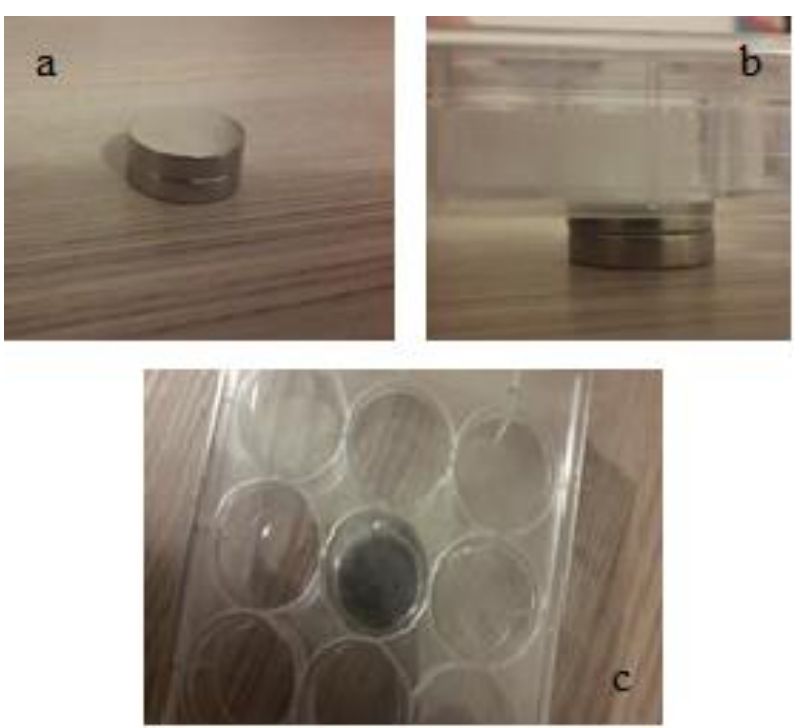

Fig. 1. Two cylindrical Neodymum-Iron-Boron $\left(\mathrm{Nd}_{2} \mathrm{Fe}_{14} \mathrm{~B}\right)$ magnets provided the $328 \mathrm{mT}$ SMF. a) All magnents were placed top on top, b) Assay wells of 12-well plates were put on surface of the magnets, c) Each of the magnets had enough surface area to cover interior surface of a well.

Determination of Cell Orientation under 328 mT SMF Influence

To observe and measure whether human BM-MSCs gain an orientation under $328 \mathrm{mT} \mathrm{SMF}$, the cells in 12well plates were grown in NutriStem Cell XF Basal Medium supplemented with NutriStem XF Supplement 
XF with or without the SMF influence for 6 days. Two separate 12-well plates were used to minimize the magnetic exposure of the control group. On day 0, 10780 cells/well were plated into the three wells of each 12-well plates. One of the plates was used as the control and was not exposed to SMF. The second plate was placed on top of the $\mathrm{Nd}_{2} \mathrm{Fe}_{14} \mathrm{~B}$ magnets. On the $6^{\text {th }}$ day, the cells were photographed under an inverted microscope with a camera attachment (Zeiss Axiovert A01-Germany). The camera was operated in 20x magnification.

All images were pre-processed with the open-source software ImageJ [http://imagej.nih.gov/ij/index.html] and a fully automated analysis of cell orientation was obtained utilizing the OrientationJ plugin.

Determination of Cell Proliferation and Growth under 328 mT SMF Influence

Two separate 12-well plates were used to minimize the magnetic exposure of the control group. On day 0 , 10780 cells/well were plated into the three wells of each 12 -well plates. One of the plates was used as the control without exposure to magnetic influence. The second plate was placed on top of the $\mathrm{Nd}_{2} \mathrm{Fe}_{14} \mathrm{~B}$ magnets. The cultures were fed with The NutriStem Cell XF Basal Medium supplemented with NutriStem XF Supplement XF. On the $6^{\text {th }}$ day, the cell growth and propagation were measured after incubation for 3 hours with MTT (3-(4,5dimethylthiazol-2-yl)- 2,5-diphenyltetrazolium bromide) salt (Cat\# M2003, Sigma-USA). After the incubation, purple/blue formazan crystals were solubilized by the addition of $300 \mu \mathrm{L}$ DMSO (dimethyl sulfoxide) (Cat\# D2650, Sigma-USA). $100 \mu \mathrm{L}$ solution was taken and measured at $570 \mathrm{~nm}$ and $650 \mathrm{~nm}$ in a spectrophotometric plate reader (BIOTEK-USA).

Determination of Biomineral Accumulation and Osteogenic Differentiation under 328 mT SMF Influence

To determine and measure biomineral accumulation and osteogenic differentiation, two control groups and two assay groups in separate 12 well plates were prepared. The cells were plated intro the three wells of each plates.. On day 0, 70000-80000 human BM-MSCs/ well were incubated in NutriStem Cell XF Basal Medium supplemented with NutriStem XF Supplement XF. On the $1^{\text {st }}$ day, all medium was changed according to the experiment setting.

The $1^{\text {st }}$ control group was the BM-MSCs which were incubated in NutriStem Cell XF Basal Medium supplemented with NutriStem XF Supplement XF. The $2^{\text {nd }}$ control group was the BM-MSCs which were incubated in Stempro Basal Medium supplemented with Stempro Osteogenesis Supplement. The $1^{\text {st }}$ assay group was the BM-MSCs that were incubated in NutriStem Cell XF Basal Medium supplemented with NutriStem XF Supplement XF under $328 \mathrm{mT}$ SMF influence. The $2^{\text {nd }}$ assay group was the BM-MSCs that were incubated in Stempro Basal Medium supplemented with Stempro Osteogenesis Supplement under 328 mT SMF influence. The experiment duration was 14 days in total.
Biomineralization was determined with Alizarin Red $\mathrm{S}$ (pH: 4.1-4.3) staining. On the $14^{\text {th }}$ day, all medium was poured out. The cells were fixed by $500 \mu \mathrm{L} 4 \%$ buffered formalin solution for 30 minutes. After washing two times with $\mathrm{dH}_{2} \mathrm{O}, 1 \mathrm{~mL}$ Alizarin Red $\mathrm{S}$ staining solution was added to every culture well and incubated for 20 minutes. After incubation, the control and assay wells were washed with $\mathrm{dH}_{2} \mathrm{O}$ four times. Stained control and assay wells were photographed.

Osteogenesis was determined with Alkaline Phosphatase (ALP) activity. On the $14^{\text {th }}$ day, all medium was poured out. The cells were lysed by two freeze and thaw cycles in phosphate buffer containing $1 \%(\mathrm{v} / \mathrm{v})$ Triton $\mathrm{x}-100$. $1 \mathrm{mg} / \mathrm{mL}$ ALP substrate (p-nitrophenol phosphate, p-npp) (20-106, Sigma-USA) solution was prepared in a solution containing $1 \mathrm{M}$ diethanolamine, 0.5 $\mathrm{M} \mathrm{MgCl}_{2}$ (pH 9.8). $75 \mu \mathrm{L}$ cell lysate and $25 \mu \mathrm{L}$ ALP substrate solutions were mixed and incubated for 20 seconds. ALP activity was measured at $405 \mathrm{~nm}$ by a spectrophotometric plate reader.

\section{Statistical Analysis}

An unpaired student t-test was used to determine the statistical significance of the differences between control and assay groups with $\mathrm{P}<0.05$ accepted as significant.

\section{Results}

\section{8 mT SMF Effects on Human BM-MSCs Orientation}

The human BM-MSCs groups grown in wells without $328 \mathrm{mT}$ SMF influence (Fig. 2a) and the human BMMSCs groups grown in wells with $328 \mathrm{mT}$ SMF influence (Fig. 2c) were photographed by 20x magnification after 6 hours of SMF exposure. OrientationJ, a plugin of Image J was used to infer the preferred orientation of structures in these images. OrientationJ computed histograms for the control groups (Fig. 2b) and the assay groups (Fig. 2d). The preferred orientation in Fig. $2 d$ was seen as a homogenous histogram with a peak. However, the control group revealed a heterogenous histogram with multiple peaks (Fig 2b).

OrientationJ was also used to produce an orientation map. The images shown in Fig. 2a and Fig. 2c were colored according to their local directionality. The multidirectionality in Fig. 2a was seen as a multi-chromic plane. However, increased mono-directionality was seen as a mono-chromic plane (Fig. 2c).

\section{$328 m T$ SMF Effects on Human BM-MSCs} Proliferation and Growth

Cell viability and growth in both the control and assay groups were determined by the MTT analysis after 8 hours of SMF exposure. Cell count in the control and assay groups reached to mean 199300 cells /well and 253744 cells/well, respectively (Table 1). The difference between the groups was not statistically significant (two-tailed $\mathrm{P}=$ $0.2055)$. 

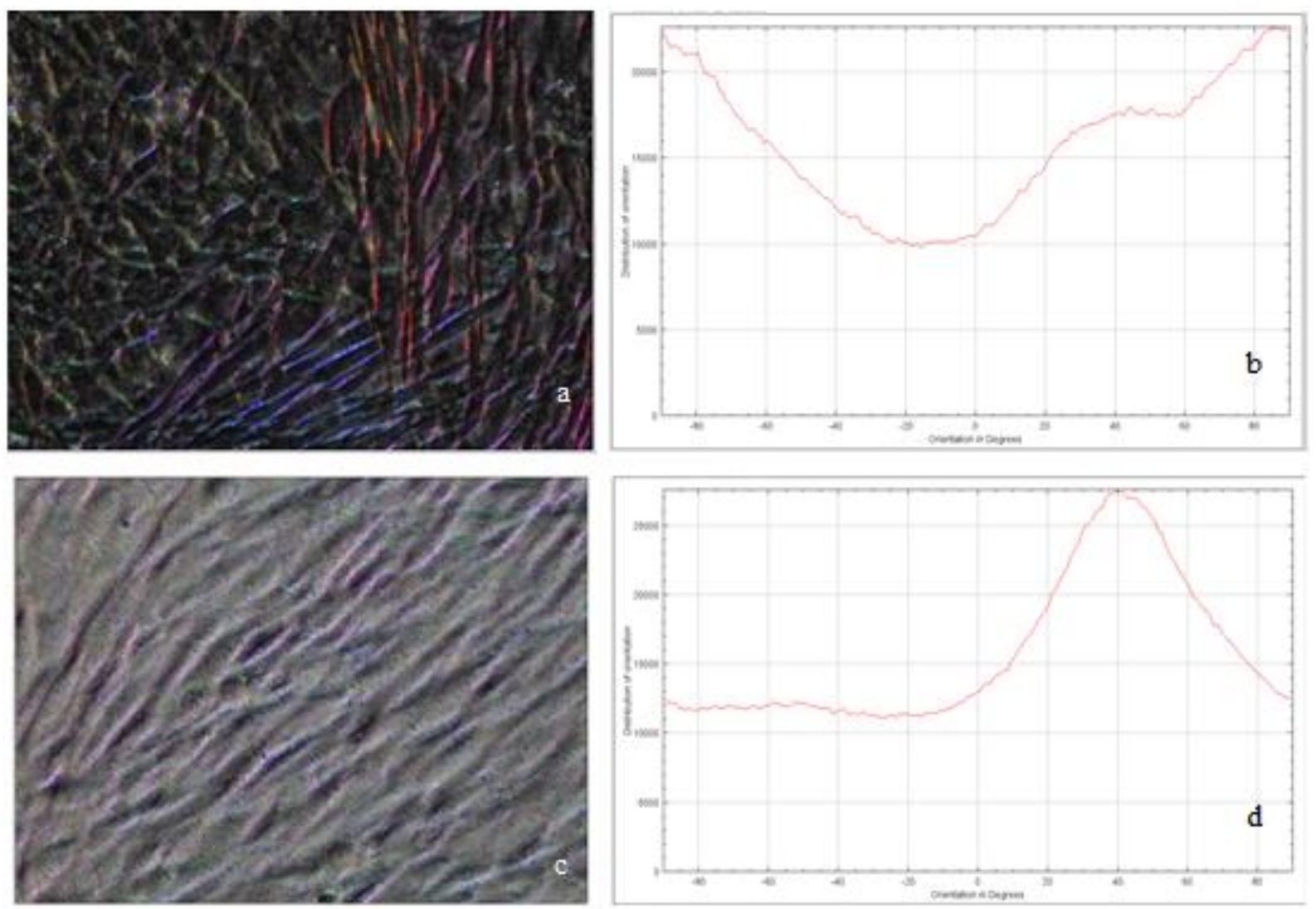

Fig. 2. $328 \mathrm{mT}$ SMF effect on the human BM-MSC orientation. All microscopic photos were taken by 20x magnification. a) The cells grown as control group without artificial SMF influence. Multichromatic cells represent multi-directionality of the cells. b) shows the orientation, in degrees, of the cells in a. c) The cells were grown as assay group with artificial $328 \mathrm{mT}$ SMF influence. Monochromatic cells irepresent mono-directionality of the cells. d) shows the orientation, in degrees, of the cells c.

Table 1. Compression of viable vell counts between the control and assay groups.

\begin{tabular}{|c|c|c|c|}
\hline $\begin{array}{c}\text { Control } \\
\text { Groups } \\
\text { (Without } 328 \\
\text { mT SMF } \\
\text { Influence) }\end{array}$ & $\begin{array}{l}\text { Viable Cell } \\
\text { Count/well }\end{array}$ & $\begin{array}{c}\text { Assay Groups } \\
\text { (With } 328 \text { mT } \\
\text { SMF } \\
\text { Influence) }\end{array}$ & $\begin{array}{c}\text { Viable } \\
\text { Cell } \\
\text { Count/well }\end{array}$ \\
\hline $\begin{array}{l}1^{\text {st }} \text { control } \\
\text { well }\end{array}$ & 134,300 & $1^{\text {st }}$ assay well & 256,633 \\
\hline $\begin{array}{l}2^{\text {nd }} \text { control } \\
\text { well }\end{array}$ & 213,800 & $\begin{array}{l}2^{\text {nd }} \text { assay } \\
\text { well }\end{array}$ & 232,300 \\
\hline $\begin{array}{l}3^{\text {rd }} \text { control } \\
\text { well }\end{array}$ & 249,800 & $3^{\text {rd }}$ assay well & 272,300 \\
\hline $\begin{array}{l}\text { Sample } \\
\text { Number }\end{array}$ & 3 & $\begin{array}{l}\text { Sample } \\
\text { Number }\end{array}$ & 3 \\
\hline Mean & 199,300 & Mean & 253,744 \\
\hline $\begin{array}{l}\text { Standard } \\
\text { Deviation }\end{array}$ & $59,099.49$ & $\begin{array}{l}\text { Standard } \\
\text { Deviation }\end{array}$ & $20,155.85$ \\
\hline \multicolumn{4}{|c|}{ two tailed $\mathrm{P}=0.2055$} \\
\hline
\end{tabular}

328 mT SMF Effects on Biomineral Accumulation and Osteogenic Differentiation of Human BM-MSCS

To observe the effect of SMF on osteogenesis, two different cell culture mediums i) Stempro Basal Medium supplemented with Stempro Osteogenesis Supplement, an osteogenesis-stimulating medium, ii) NutriStem Cell XF Basal Medium for proliferation were compared. The osteogenesis process of BM-MSCs under the $328 \mathrm{mT}$ SMF was evaluated by measuring ALP activity and biomineralization.

ALP activity of the cells were compared on the $14^{\text {th }}$ day of incubation in NutriStem Cell XF Basal Medium supplemented with NutriStem XF Supplement XF with or without continuous $328 \mathrm{mT}$ SMF treatment. The mean values of ALP activities of the cells treated and nontreated by continuous $328 \mathrm{mT}$ SMF for 14 days were 11.844 IU/L and 13.575 IU/L, respectively (Table 2). Statistical evaluation of the ALP activities between the groups showed that the effect of SMF exposure was not significantly different (two-tailed $\mathrm{P}=0.1015$ ).

Osteogenesis was induced using the Stempro Osteogenesis Differentiation Kit and ALP activities of the cells were compared after 14 days of incubation in Stempro Basal Medium supplemented with Stempro Osteogenesis Supplement with or without continuous 328 mT SMF treatment. The mean ALP activities of the cells treated and non-treated by continuous $328 \mathrm{mT}$ SMF for 14 days were $31.367 \mathrm{IU} / \mathrm{L}$ and $25.966 \mathrm{IU} / \mathrm{L}$, respectively (Table 3). Results showed that the difference between ALP activities of the two groups was statistically significant (two-tailed $\mathrm{P}=0.0336$ ). 
Table 2. IU/ALP activities of human BM-MSCs were grown in NutriStem Cell XF Basal Medium supplemented with NutriStem XF Supplement XF without or with $328 \mathrm{mT}$ SMF treatment.

\begin{tabular}{|c|c|c|c|}
\hline $\begin{array}{c}1^{\text {st }} \text { control } \\
\text { (Without } 328 \\
\text { mT SMF } \\
\text { Influence) }\end{array}$ & $\begin{array}{l}1^{\text {st }} \\
\text { control } \\
\text { IU/ALP } \\
\text { Activity }\end{array}$ & $\begin{array}{c}1^{\text {st }} \text { assay } \\
\text { (With } 328 \\
\text { mT SMF } \\
\text { Influence) }\end{array}$ & $\begin{array}{l}\text { 1 }^{\text {st }} \text { assay } \\
\text { IU/ALP } \\
\text { Activity }\end{array}$ \\
\hline Control well & 10.549 & Assay well & 13.216 \\
\hline Control well & 11.701 & Assay well & 13.589 \\
\hline Control well & 13.280 & Assay well & 13.920 \\
\hline $\begin{array}{l}\text { Sample } \\
\text { Number }\end{array}$ & 3 & $\begin{array}{l}\text { Sample } \\
\text { Number }\end{array}$ & 3 \\
\hline Mean & 11.844 & Mean & 13.575 \\
\hline $\begin{array}{l}\text { Standard } \\
\text { Deviation } \\
\text { two-tailed } \mathrm{P}=\end{array}$ & $\begin{array}{l}1.371 \\
015\end{array}$ & $\begin{array}{l}\text { Standard } \\
\text { Deviation }\end{array}$ & 0.352 \\
\hline
\end{tabular}

Table 3. IU/ALP activities of human BM-MSCs were grown in Stempro Basal Medium supplemented with Stempro Osteogenesis Supplement without or with $328 \mathrm{mT}$ SMF treatment.

\begin{tabular}{llll}
\hline \hline $\begin{array}{l}\mathbf{2}^{\text {nd }} \text { control } \\
\text { (Without 328 } \\
\text { mT SMF } \\
\text { Influence) }\end{array}$ & $\begin{array}{c}\mathbf{2}^{\text {nd }} \text { control } \\
\text { IU/ALP } \\
\text { Activity }\end{array}$ & $\begin{array}{c}\mathbf{2}^{\text {nd }} \text { assay } \\
\text { (With 328 } \mathbf{~ m T} \\
\text { SMF } \\
\text { Influence) }\end{array}$ & $\begin{array}{c}\mathbf{2}^{\text {nd }} \text { assay } \\
\text { IU/ALP } \\
\text { Activity }\end{array}$ \\
\hline \hline Control well & 30.709 & Assay well & 26.517 \\
\hline $\begin{array}{l}\text { Control well } \\
\text { Control well }\end{array}$ & 32.768 & Assay well & 23.051 \\
$\begin{array}{l}\text { Sample } \\
\text { Number }\end{array}$ & $\mathbf{3}$ & Assay well & 28.331 \\
$\begin{array}{l}\text { Mean } \\
\text { Standard } \\
\text { Deviation } \\
\text { two-tailed P }=0.0336\end{array}$ & $\mathbf{3 1 . 3 6 7}$ & $\begin{array}{l}\text { Sample } \\
\text { Number } \\
\text { Mean } \\
\text { Standard }\end{array}$ & $\mathbf{3}$ \\
\hline \hline
\end{tabular}

Biomineralization was compared by Alizarin Red S staining at the end of the $14^{\text {th }}$ day of incubation in NutriStem Cell XF Basal Medium supplemented with NutriStem XF Supplement XF with or without continuous $328 \mathrm{mT}$ SMF treatment. No difference was observed in staining patterns between the control and assay groups (Fig. 3a, b). When biomineralization was compared by Alizarin Red S staining in Stempro Basal Medium supplemented with Stempro Osteogenesis Supplement with or without continuous $328 \mathrm{mT}$ SMF treatment, the results showed that the staining in the groups treated continuous $328 \mathrm{mT} \mathrm{SMF}$ for 14 days was less than the groups grown without $328 \mathrm{mT}$ SMF influence (Figs 4a, b).

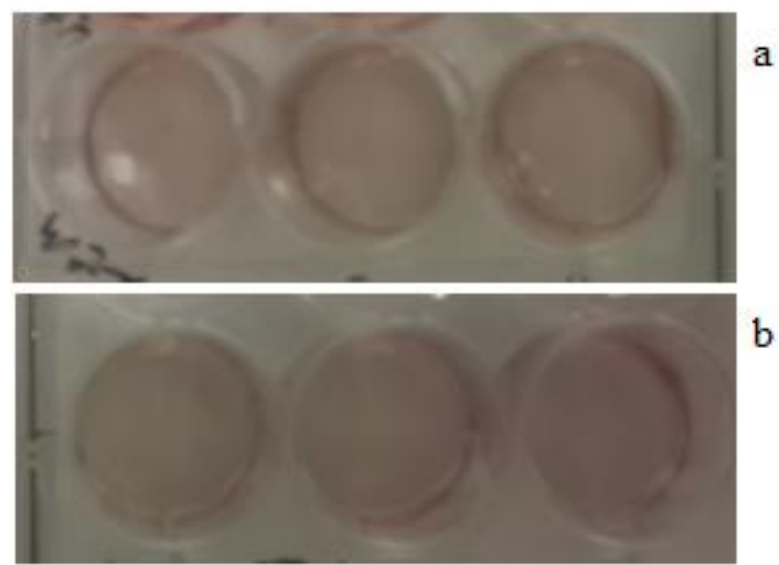

Fig. 3. After Alizarin Red S staining, comparison of the $1^{\text {st }}$ control and $1^{\text {st }}$ assay. a) $1^{\text {st }}$ control, human BM-MSCs were grown in NutriStem Cell XF Basal Medium supplemented with NutriStem XF Supplement XF without 328 mT SMF Treatment, b) $1^{\text {st }}$ assay, human BM-MSCs were grown in NutriStem Cell XF Basal Medium supplemented with NutriStem XF Supplement XF with $328 \mathrm{mT}$ SMF treatment.

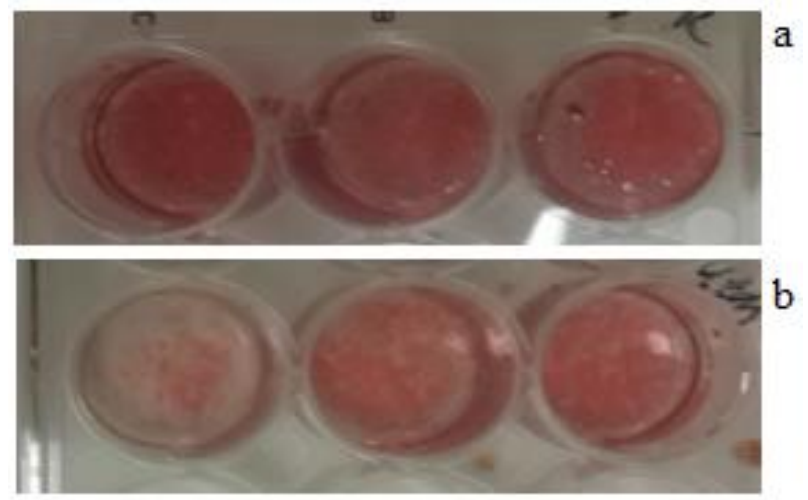

Fig. 4. After Alizarin Red $S$ staining, comparison of the $2^{\text {nd }}$ control and $2^{\text {nd }}$ assay. a) $2^{\text {nd }}$ control, human BM-MSCs were grown in Stempro Basal Medium supplemented with Stempro Osteogenesis Supplement without $328 \mathrm{mT}$ SMF treatment, b) $2^{\text {nd }}$ assay, human BM-MSCs were grown in Stempro Basal Medium supplemented with Stempro Osteogenesis Supplement with $328 \mathrm{mT}$ SMF treatment.

\section{Discussion}

A natural magnetic field (geomagnetic field) or an artificial magnetic field is a physical parameter of the environment just as temperature, humidity, or altitude. Magnetic fields impact biological or organic systems as well as inorganic systems or matters. These influences are determined by magnetic susceptibility of the objects, magnetic field intensity or magnetic field flux density, and gradient. However, the kind of a magnetic field source (an electrical flux or a permanent magnet) has no special effect on the results. Salmons and turtles determine their natal homing behavior by the geomagnetic changes or intensities (Lohmann \& Lohmann 2019). Cells can give responses to any magnetic field with their various structures or biomolecules (membranes, mitochondria, nucleic acids, and proteins) (Zhang et al. 2017a). In this 
preliminary study, $\mathrm{Nd}_{2} \mathrm{Fe}_{14} \mathrm{~B}$ magnets easily produced a SMF. In the SMF, the magnetic field intensity or magnetic field flux density does not change according to time. The geomagnetic field and magnetic field used in Magnetic Resonance Imagining (MRI) are the SMF. It is a more suitable magnetic field with less changeable parameters to observe its influence or effects on biological systems. The SMFs are classified according to their magnetic flux density (B) as weak (<1 mT), moderate (1 mT-1 T), strong (1 T-5 T), and ultrastrong (>5 T) (Zhang et al. 2017b). Although there is substantial evidence on the biological effects of moderate SMF, the results of the effects are controversial, and the mechanism of the effects are still not clear. In this study, moderate $(328 \mathrm{mT}) \mathrm{SMF}$ effects on cells were evaluated.

Mesenchymal stem/stromal cells (MSCs) with differentiation ability to multiple into mesodermal cell types (osteoblast, chondrocyte, and adipocyte) and modulative secretome are the main tools for regenerative medicine and cell therapies (Fitzsimmons et al. 2018). Although the MSCs were isolated and propagated from various tissues or tissue areas including bone marrow, adipose tissue, dental pulp, placenta, Wharton Jelly, umbilical cord blood, and other perivascular areas with similar phenotypic characteristics and differentiation abilities, bone marrow-derived MSCs (BM-MSCs) are the most extensively studied one, especially for bone regeneration and osteogenesis.

The MSCs cultured in vitro can be chemically induced to differentiate to the bone and other mesodermal cell types. Common biochemical agents and growth factors for osteogenesis are dexamethasone, indomethacin, and Bone Morphogenic Proteins (BMPs). Tissue regeneration methods utilize these factors to produce tissue constructs in vitro that are ready for implantation in vivo and to reduce healing time. MSCs are also highly mechanosensitive in vitro and in vivo. A mechanical stimulation as tensile strain induces MSCs for osteogenesis and tendogenesis but inhibits adipogenesis. Other mechanical stimulations as hydrostatic pressure and compressive loading induce MSCs for chondrogenesis. Therefore, mechanical stimulations are also another effector for tissue regeneration methods to determine or modulate MSCs fate (Delaine-Smith \& Reilly 2012). The $\mathrm{SMF}$ is one of the mechanical stimulants for cellular structures and electrochemical flux on cellular membranes. However, its effects on especially stem cell physiology are poorly discussed. If there are any SMF effects on stem cell fate, its degree, condition and mechanism should be determined by detailed studies (Marycz et al. 2018).

Murayama et al. (1965) were the first to report cell orientation under SMF influence. Deoxygenized sickled erythrocytes in a suspension gained a pendicular orientation under 0,35 T SMF influence. Kotani et al. (2002) observed MC3T3-E1 cells orientation toward magnetic field flux direction after constant 60 hours of 8 T SMF influence. Ogiue-Ikeda et al. (2004) showed that
A7r5 cells (smooth muscle cell, spindle shape) were orientated after a 60 hour magnetic field (8T) exposure only when the cells were seeded with high cell density $\left(1 \times 10^{5}\right.$ cells $\left./ \mathrm{cm}^{2}\right)$. On the other hand, when the cells were in confluent condition at the start point of the magnetic field exposure, the cells were not oriented. Sadri et al. (2018) showed that Wharton Jelly derived mesenchymal stem cells gain parallel orientation in 8 hours and $18 \mathrm{mT}$ SMF influence. However, orientation in SMF influence depends on cell shape. For example, Human kidney HFK293 cells in $8 \mathrm{~T}$ SMF influence and Human glioblastoma cells $10 \mathrm{~T}$ SMF influence, which are both polygonal shaped cells preferred orientation was not observed. Also, cellular orientation in the SMF influence depends on magnetic flux density or magnetic intensity. This orientation tendency is produced by the SMF influence on non-global diamagnetic anisotropic particles or molecules. This creates a torque on these structures. This effect is especially seen in membrane proteins, microtubes and actin filaments (Zhang, et al. 2017b). In our study, we observed that human BM-MSCs in high density but still proliferating cultures gain orientation in moderate 328 mT SMF influence (Figs 2a-d). Although the floating cells as erythrocytes gain an orientation under a static magnetic field in few seconds, the time for adherent cells such as osteoblasts gaining an orientation is in 10 times longer. The starting cell density and assay duration give a chance for orientation under the static magnetic field exposure.

There are contradictory results about the SMF effect on cell proliferation and growth. Kim et al. (2015) observed an increased BM-MSC proliferation during 3 $\mathrm{mT}, 15 \mathrm{mT}$, and $50 \mathrm{mT} \mathrm{SMF}$ treatment for 1, 3, 5, 7, and 9 days exposures, respectively. Maredziak et al. (2017) also determined an increasing proliferation in adipose tissue-derived MSCs in 0,5 T SMF treatment for 7 days. However, Silva et al. (2018) observed decreased viability of mouse BM-MSC with or without magnetized nanoparticles in 0.3-0.45 T SMF treatment for 48 hours. Cunha et al. (2012) also observed decreased proliferation and growth rate of human osteoblast in $320 \mathrm{mT} \mathrm{SMF}$ treatment for 1, 3, and 7 days. Yamamato et al. (2003) observed an unchanged proliferation and growth rates of rat osteoblasts in $280 \mathrm{mT}$ or $340 \mathrm{mT} \mathrm{SMF}$ treatment for 2 , $4,6,8$, and 10 days. We also observed an unchanged proliferation and growth rate of human BM-MSC in 328 mT SMF for 6 days (Table 1 and Fig. 3). Yamamato et al. (2003) explained the unchanged proliferation rates as an increased S phase but non-triggered G2/M transition.

A metalloenzyme Alkaline Phosphatase (ALP) is expressed in high concentrations in bone tissues and hydrolases phosphomonoesters. During biomineralization, ALP local concentration increases and triggers the process. ALP activity decreases and the bones become soft with insufficient biomineralization in a heredity hypo-phosphatase disorder (Golub \& BoeszeBattaglia 2007). In this study, the ALP activity was compared between groups treated with or without 
continuous $328 \mathrm{mT}$ SMF for 14 days. It was observed that the ALP activity decreased in the groups treated with 328 mT SMF. Decreased biomineralization or staining with Alizarin Red S was also seen in the groups treated with continuous $328 \mathrm{mT}$ SMF for 14 days. Wang et al. (2016) observed a decreased osteogenic differentiation in adipose tissue-derived MSCs treated with continuous $0.5 \mathrm{~T}$ for 7 days. Also, Yang et al. (2018) observed a decreased ALP activity and biomineralization in MC3T3-E1 cells treated continuous $200 \mathrm{mT}$ SMF for 8 days. However, there are also contradictory results in this regard. Increased ALP activity and biomineralization in MC3T3-E1 cells treated with 16 T SMF were observed (Yang et al. 2018).

In conclusion, a static magnetic field is an easily obtainable and controllable physical stimulant for organisms and cells. Therefore, it can be an effective medical tool. MSCs have a main role in tissue

\section{References}

1. Brown, C., McKee, C., Bakshil, S., Walker, K., Hakman, E., Halassy, S., Svinarich, D., Dodds, R., Govind, C.K. \& Chaudhry, G.R. 2019. Mesenchymal stem cells: Cell therapy and regeneration. Journal of Tissue Engineering and Regenerative Medicine, 13(9): 1738-1755. https://doi.org/ 10.1002/term.2914

2. Cunha, C., Panseri, S., Marcacci, M., Tampieri, A. 2012. Evaluation of the effects of a moderate intensity static magnetic field application on human osteoblast-like cells. American Journal of Biomedical Engineering, 2(6): 263268. https://doi.org/10.5923/j.ajbe.20120206.05

3. Delaine-Smith, R.M. \& Reilly, G.C. 2012. Mesenchymal stem cell responses to mechanical stimuli. Muscles Ligaments Tendons Journal, 2(3): 169-180.

4. Fitzsimmons, R.E.B., Mazurek, M.S., Soos, A. \& Simmons, C.A. 2018. Mesenchymal stromal/stem cells in regenerative medicine and tissue engineering. Stem Cell International, 2018: 8031718. https://doi.org/10.1155/2018/8031718

5. Friedenstein, A.J., Piatetzky Shapiro I.I. \& Petrakova, K.V. 1966. Development in transplants of bone marrow cells. Journal of Embryology and Experimental Morphology, 16(3): 381-390.

6. Guilak, F., Cohen, D.M., Estes, B.T., Gimble, J.M., Liedtke, W. \& Chen, C.S. 2009. Control of stem cell fate by physical interactions with the extracellular matrix. Cell Stem Cell, $5(1): 17-26$. https://doi.org/10.1016/j.stem.2009.06.016

7. Golub, E. \& Boesze-Battaglia, K. 2007. The role of alkaline phosphatase in mineralization. Current Opinion in Orthopaedics, $\quad 18(5)$ : $444-448$. https://doi.org/10.1097/BCO.0b013e3282630851

8. Keating, A. 2017. The nomenclature of mesenchymal stem cells and mesenchymal stromal cells, pp. 8-10. In: Atkinson, K. (ed.). The Biology and Therapeutic Application of Mesenchymal Cells. New John Wiley \& Sons, Jersey, 965 pp.

9. Kim, E.C., Leesungbok, R., Lee, S., Lee, H.W., Park, S.H., Mah, S.J. \& Ahn, S.J. 2015. Effects of moderate intensity regeneration and cell therapies by differentiation and paracrine effects. Their affectivity and distribution can be controlled by the SMF influence.

Ethics Committee Approval: Since the article does not contain any studies with human or animal subject, its approval to the ethics committee was not required.

Author Contributions: Design: E.O., Execution: K.M., Data analysis/interpretation: K.M., E.O., Manuscript writing: K.M., E.O.

Conflict of Interest: The authors have no conflicts of interest to declare.

Funding: This work was supported by the Research Fund of Yildiz Technical University, Project Number: FYL-2019-3520.

static magnetic fields on human bone marrow-derived mesenchymal stem cells. Bioelectromagnetics, 36(4): 267276. https://doi.org/10.1002/bem.21903

10. Kotani, H., Kawaguchi, H., Shimoaka, T., Iwasaka, M., Ueno, S., Ozawa, H., Nakamura, K. \& Hoshi, K. 2002. Strong static magnetic field stimulates bone formation to a definite orientation in vitro and in vivo. Journal of Bone and Mineral Research, 17(10): 1814-1821. https://doi.org/10.1359/jbmr.2002.17.10.1814

11. Lohmann, K.J. \& Lohmann, C.M. 2019. There and back again: natal homing by magnetic navigation in sea turtles and salmons. Journal of Experimental Biology, 222 (Pt Suppl 1): jeb184077. https://doi.org/10.1242/jeb.184077

12. Marędziak, M., Tomaszewski, K., Polinceusz, P., Lewandowski, D. \& Marycz, K. 2017. Static magnetic field enhances the viability and proliferation rate of adipose tissue-derived mesenchymal stem cells potentially through activation of the phosphoinositide 3kinase/Akt (PI3K/Akt) pathway. Electromagnetic Biology and Medicine, 36(1): 45-54. https://doi.org/10.3109/15368378.2016

13. Markov, M.S. 2007. Magnetic field therapy: a review. Electromagnetic Biology and Medicine, 26(1): 1-23. https://doi.org/10.1080/15368370600925342

14. Markov, M.S. 2015. XXI ${ }^{\text {st }}$ Century megnetotherapy. Electromagnetic Biology and Medicine, 34(3): 190-196. https://doi.org/10.3109/15368378.2015.1077338

15. Marycz, K., Kornicka, K. \& Röcken, M. 2018. Static magnetic field (SMF) as a regulator of stem cell fate-new perspectives in regenerative medicine arising from an underestimated tool. Stem Cell Reviews and Reports, 14(6): 785-792. https://doi.org/10.1007/s12015-018-9847-4

16. Murayama, M. 1965. Orientation of sickled erythrocytes in a magnetic field. Nature, 206(982): 420-422. https://doi.org/10.1038/206420a0

17. Ogiue-Ikeda, M. \& Ueno, S. 2004. Magnetic Cell Orientation Depending on Cell Type and Cell Density. 
IEEE Transections on Magnetics, 40(4): 3024-3026. https://doi.org/10.1109/TMAG.2004.830453

18. Rajabzadeh, N., Fathi, E. \& Farahzadi, R. 2019. Stem cellbased regenerative medicine. Stem Cell Investigation, 6(19). https://doi.org/10.21037/sci.2019.06.04

19. Sadri, M., Abdolmaleki, P., Behmanesh, M., Abrun, S., Beiki, B. \& Samani, F.S. 2017. Static magnetic field effect on cell alignment, growth and differentiation in human cord-derived mesenchymal stem cells. Cellular and Molecular Engineering, 10(3): 249-262. https://doi.org/10.1007/s12195-017-0482-y

20. Silva, L.H., Silva, S.M., Lima, E.D., Silva, R.C., Weiss, D.J., Morales, M.M., Cruz, F.F. \& Rocco, P.R.M. 2018. Effects of static magnetic fields on natural or magnetized mesenchymal stromal cells: Repercussions for magnetic targeting, Nanomedicine, 14(7): 2075-2085. https://doi.org/10.1016/j.nano.2018.06.002

21. Stefanita, C.G. 2012. Traditional Magnetism. pp. 1-38. In: Stefanita, C.G. (ed.). Magnetism: Basic and Application. Springer, London, $188 \mathrm{pp}$.

22. Suman, S., Domingues A, Ratajczak J. \& Ratajczak MZ. 2019. Potential clinical applications of stem cells in regenerative medicine. Advances in Experimental Medicine and Biology, 1201:1-22. https://doi.org/10.1007/978-3030-31206-0_1

23. Trohatou, O. \& Roubelakis, M.G. 2017. Mesenchyal stem/stromal cells in regenerative medicine: past, present and future. Cellular Programming, 19(4): 217-224. https://doi.org/10.1089/cell.2016.0062
24. Yamamato, Y., Ohsaki, Y., Goto, T., Nakasima, A. \& Lijima, T. 2003. Effects of static magnetic fields on bone formation in rat osteoblast cultures. Journal of Dental Research, 82(12): 962-966. https://doi.org/10.1177/154405910308201205

25. Yang, J., Zhang, J., Ding, C., Dong, D. \& Shang, P. 2018. Regulation of osteoblast differentiation and iron content in MC3T3-E1 cells by static magnetic field with different intensities. Biological Trace Element Research, 184(1): 214-225. https://doi.org/10.1007/s12011-017-1161-5

26. Wang, X.B., Xiang, B., Deng, J., Freed, D.H., Arora, R. \& Tian, G. 2016. Inhibition of viability, proliferation, cytokines secretion, surface antigen expression, and adipogenic and osteogenic differentiation of adiposederived stem cells by seven-day exposure to $0.5 \mathrm{~T}$ static magnetic fields. Stem Cells International, 2016: 7168175. https://doi.org/10.1155/2016/7168175

27. Wills, B.A. \& Finch, J.A. 2015. Magnetic and Electrical Separation. pp. 381-407. In: Wills BA, Finch JA (eds). Wills' Mineral Processing Technology. Elsevier, Butterworth-Heinemann, $512 \mathrm{pp}$.

28. Zhang, X., Yarema, K. \& Xu, A. 2017a. Parameters of Magnetic Fields and Their Differential Biological Effects. 3-25. In: Zhang, X., Yarema, K. \& Xu, A. (eds). Biological Effects of Static Magnetic Fields. Springer, Singapore, 172 pp.

29. Zhang, X., Yarema, K. \& Xu, A. 2017b. Impact of Static Magnetic Fields (SMFs) on Cells. 81-131. In: Zhang, X., Yarema, K. \& Xu, A. (eds). Biological Effects of Static Magnetic Fields. Springer, Singapore, 172 pp. 